Article

\title{
Democracy and Human Rights: Concepts, Measures, and Relationships
}

\author{
Todd Landman \\ School of Politics and International Relations, University of Nottingham, Nottingham, NG7 2RD, UK; \\ E-Mail: todd.landman@nottingham.ac.uk
}

Submitted: 28 September 2017 | Accepted: 20 November 2017 | Published: 19 March 2018

\begin{abstract}
The empirical literature on democracy and human rights has made great strides over the last 30 years in explaining (1) the variation in the transition to, consolidation of, and quality of democracy; (2) the proliferation and effectiveness of human rights law; and (3) the causes and consequences of human rights across many of their categories and dimensions. This work has in many ways overcome the 'essentially contested' nature of the concepts of democracy and human rights conceptually, established different measures of both empirically, and developed increasingly sophisticated statistical and other analytical techniques to provide stronger inferences for the academic and policy community. This article argues that despite these many achievements, there remain tensions between conceptualisations of democracy and human rights over the degree to which one includes the other, the temporal and spatial empirical relationships between them, and the measures that have been developed to operationalize them. These tensions, in turn, affect the kinds of analyses that are carried out, including model specification, methods of estimation, and findings. Drawing on extant theories and measures of both, the article argues that there must be greater specificity in the conceptualisation and operationalization of democracy and human rights, greater care in the development and use of measures, and greater attention to the kinds of inferences that are made possible by them.
\end{abstract}

\section{Keywords}

administrative data; big data; democracy; events data; human rights; measurement; socio-economic; standards data; statistics; survey data

\section{Issue}

This article is part of the issue "Why Choice Matters: Revisiting and Comparing Measures of Democracy", edited by Heiko Giebler (WZB Berlin Social Science Center, Germany), Saskia P. Ruth (German Institute of Global and Area Studies, Germany), and Dag Tanneberg (University of Potsdam, Germany).

(C) 2018 by the author; licensee Cogitatio (Lisbon, Portugal). This article is licensed under a Creative Commons Attribution 4.0 International License (CC BY).

\section{Introduction}

In 1971, Robert Dahl published Polyarchy in which he set out a systematic framework for measuring and understanding two fundamental dimensions of democracy: contestation and inclusiveness. The combination of these two dimensions allowed for comparative analysis of a variety of regime types around the world, while normatively his concept of 'polyarchy', which included countries with a high degree of contestation and a high degree of inclusiveness, was argued to be the most preferred system of governance. In 1988, Neil Mitchell and James McCormick published one of the first systematic comparative analyses of human rights in the journal World Poli- tics, which explained the cross-national variation in the protection of civil and political rights. Both of these publications and analyses relied on (1) systematic theorisation of the concepts under inquiry, (2) methods for measuring the concepts, and (3) analysis of variation and covariation within and between the measures across country cases (see Adcock \& Collier, 2001, p. 531; Landman \& Carvalho, 2009, pp. 32-34). Since these seminal publications on the empirical analysis of democracy and human rights, there have been countless studies on the (1) the variation in the transition to, consolidation of, and quality and performance of democracy; (2) the proliferation and effectiveness of human rights law; and (3) the causes and consequences of human rights across many 
of their different categories and dimensions (see Landman, 2005b, 2009, 2013).

This kind of work has in many ways overcome the 'essentially contested' (Gallie, 1956) nature of democracy and human rights conceptually, established different and highly varied measures of both, and developed increasingly sophisticated statistical and other analytical techniques that provide stronger inferences for the academic and policy community. This article argues that despite these many achievements, tensions remain between theories of democracy and human rights over the degree to which one includes the other, the temporal and spatial empirical relationships between and among them, and the measures that have been developed to operationalize them. These tensions, in turn, affect the kinds of analyses that are carried out, including model specification, methods of estimation, and findings. Drawing on extant theories and measures of both, the article argues that there must be greater specificity in the conceptualisation and operationalization of democracy and human rights, care in the development and use of measures, and more attention to the kinds of inferences that they make possible.

The overall motivation for this article is to provide clarity about what we mean when we talk about democracy and human rights, the degree to which they might share certain but not all attributes, and to unpack the conceptual and empirical relationships that are evident between them. Establishing conceptual clarity informs our consideration of measurement strategies and consequently any empirical relationships between democracy and human rights that might be discovered. It is important not to conflate or elide democracy and human rights. It is equally important to show how, why, and to what degree the two are inter-related, focusing on the direction, magnitude, and significance of the relationship, while at the same time remaining conscious that such relationships to date fall far below perfect correlation. This empirical gap between democracy and human rights is crucial for understanding the political challenge of progressing human rights to be closer to their legal ideal.

In order to develop these arguments, the article is structured in four sections. The first section provides a brief overview of the definition of democracy and human rights to show where and how the two concepts have a variable degree of overlap with one another. The second section shows the different strategies for measuring democracy and human rights, including (1) events-based data, (2) 'standards-based' data, (3) survey based data, (4) socio-economic and administrative data and (5) big data analytical techniques. The third section provides an overview of many of the stylized facts about the empirical relationships between measures of democracy and human rights, as well as the tendency for empirical studies to use human rights measures as measures of democracy, repression, rule of law, and good governance. The discussion shows how the associations made in theory can be tested empirically. The final section examines the remaining challenges and limitations to the current state of measurement and analysis of democracy and human rights.

\section{Democracy and Human Rights}

Democracy and human rights are grounded in the shared principles of accountability, individual liberty, integrity, fair and equal representation, inclusion and participation, and non-violent solutions to conflict. Modern conceptions of democracy are based on the fundamental ideas of popular sovereignty and collective decision making in which rulers through various ways are held to account by those over whom they rule (see Beetham, Carvalho, Landman, \& Weir, 2008; Landman, 2013). But beyond this basic consensus, there are many varieties of democracy (see Coppedge, Lindberg, \& Skaaning, 2016) or 'democracy with adjectives' (Collier \& Levitsky, 1997) that have been in use by scholars, practitioners and policy makers. These definitions can be grouped broadly into three main types: (1) procedural democracy, (2) liberal democracy, and (3) social democracy, the delineation of which largely rests on the variable incorporation of different rights protections alongside the general commitment to popular sovereignty and collective decision making. Understanding these different types of democracy and the degree to which they incorporate different categories of human rights affects the ways in which measures of both can and have been used for empirical research (Dooresnspleet, 2015; Landman, 2013, 2016; Landman \& Carvalho, 2009, 2017; Landman \& Häusermann, 2003). Absence of consideration of these lines of overlap has led to conceptual and empirical confusion in the literature on democracy and human rights, as well as in those studies that incorporate measures of either concept in their modelling strategies (see Munck, 2009).

Procedural definitions of democracy are most closely aligned with Robert Dahl's (1971) formulation in Polyarchy and include the two dimensions of contestation and participation. Contestation captures the uncertain peaceful competition necessary for democratic rule; a principle which presumes the legitimacy of a significant and organised opposition, the right to challenge incumbents, protection of the twin freedoms of expression and association, the existence of free and fair elections, and a consolidated political party system. Such a procedural definition of democracy can be considered a baseline set of conditions and a minimum threshold that can be used to assess and count the number of democracies in the world (see, e.g. Banks, 1971; Landman, 2013, pp. 3-5; Przeworski, Alvarez, Cheibub, \& Limongi, 2000).

Liberal definitions of democracy preserve the notions of contestation and participation found in procedural definitions, but add more explicit references to the protection of certain human rights. Definitions of liberal democracy thus contain an institutional dimension and a rights dimension (see Foweraker \& Krznaric, 2000). 
The institutional dimension captures the idea of popular sovereignty, and includes notions of accountability, constraint of leaders, representation of citizens, and universal participation in ways that are consistent with Dahl's 'polyarchy' model outlined above. The rights dimension is upheld by the rule of law, and includes civil, political, property, and minority rights. Such a definition is arguably richer (or 'thicker') as it includes legal constraints on the exercise of power to complement the popular elements in the derivation of and accountability for power (Coppedge, 2012, pp. 17-33).

Social definitions of democracy maintain the institutional and rights dimensions found in liberal models of democracy but expand the types of rights that ought to be protected, including social, economic and cultural rights (although some of these are included in minority rights protection seen in liberal definitions) (Beetham, 1999; Brandal, Bratberg, \& Thorsen, 2013; Doorenspleet, 2005; Landman, 2005, 2013, 2016; Macpherson, 1973; Przeworski, 1985; Sørensen, 1993). This expanded form of democracy, extends 'the democratic principle from the political to the social, in effect primarily economic, realm' (Przeworski, 1985, p. 7). In the terms deployed here, the concept of social democracy thus includes the provision of social and economic welfare and the progressive realisation of economic and social rights. It could also be argued that it includes the protection of cultural rights, which are concerned with such issues as mother tongue language, ceremonial land rights, and intellectual property rights relating to cultural practices (e.g. indigenous healing practices and remedies that may be of interest to multinational companies).

In their modern manifestation, human rights have become an accepted legal and normative standard through which to judge the quality of human dignity (Landman $\&$ Carvalho, 2009). This standard has arisen through the concerted efforts of thousands of people over many years inspired by a simple set of ideas that have become codified through the mechanism of public international law and realized through the domestic legal frameworks and governmental institutions of states around the world (Landman, 2005a, 2005b; Landman \& Carvalho, 2009). While the 1948 Universal Declaration of Human Rights makes reference to the right to take part in government (including through direct or indirect representatives, equal access to public services, and through periodic elections), the non-binding nature of the Universal Declaration of Human Rights along with a paucity of specific reference to democracy itself in subsequent international human rights instruments, means that human rights as such have been more legally codified through international human rights law than democracy.

According legal recognition to the moral claim of human rights through international law means that states are legally obliged to ensure that they respect, protect, and fulfil these claims (see, e.g. Koch, 2005). There is no corresponding legal obligation to respect, protect, and fulfil democracy in the same way as there is for rights, which provides a stronger foundation and core content for human rights than for democracy. As we shall see empirically, however, democracy is a form of government that appears superior to other forms of government for protecting, respecting and fulfilling human rights obligations. Respecting human rights requires the state to refrain from violating them. Protecting human rights requires the state to prevent the violation of human rights by 'third' parties, such as private companies, non-governmental organisations, paramilitary and insurgency groups, and 'uncivil' or undemocratic movements (see Payne, 2000). Fulfilling human rights requires the states to invest in and implement policies for the progressive realisation of human rights (Koch, 2005; Landman \& Carvalho, 2009; Landman \& Kersten, 2016).

Civil and political rights protect the 'personhood' of individuals and their ability to participate in the public activities of their countries. Economic, social and cultural rights provide individuals with access to economic resources, social opportunities for growth and the enjoyment of their distinct ways of life, as well as protection from the arbitrary loss of these rights. Solidarity rights seek to guarantee for individuals access to public goods like development and the environment, and some have begun to argue, the benefits of global economic development (Freeman, 2017; Landman, 2006; Landman \& Carvalho, 2009). Taken together, there are now a large number of human rights that have been formally codified, which can be enumerated from the different treaties that have been designed to protect them.

In following Beetham (1999, p. 94) and the brief discussion of democracy and human rights, it is clear that different conceptions of democracy vary precisely around the question of the degree of overlap and interaction between the institutional and rights dimensions. Beetham (1999, p. 94) visualises this overlap as a Venn diagram with democracy in one circle and human rights in another, where different definitions and conceptualisations of democracy necessarily reflect smaller and larger degrees of overlap (see Figure 1). Thin or procedural definitions of democracy afford less space for human rights than thicker or social definitions, while it may be possible to conceive of some attributes of human rights sitting outside the conceptual space of democracy. By thinking of the association between democracy and human rights in this way, Beetham (1999) avoids the problem that democracy and human rights might be construed as mutually constitutive of one another while retaining the notion that they are 'inter-dependent and mutually reinforcing' (United Nations, 1993). Hill (2016) makes the case that respect for personal integrity is a sine qua non for the existence of democracy and argues that democracy and human rights are thus mutually constitutive. In the terms set out here, however, Hill's (2016) argument only focuses on physical integrity rights, which means that his conception of democracy sees a permanent overlap between the institutional dimension of democracy and this more limited set of human rights, which typi- 

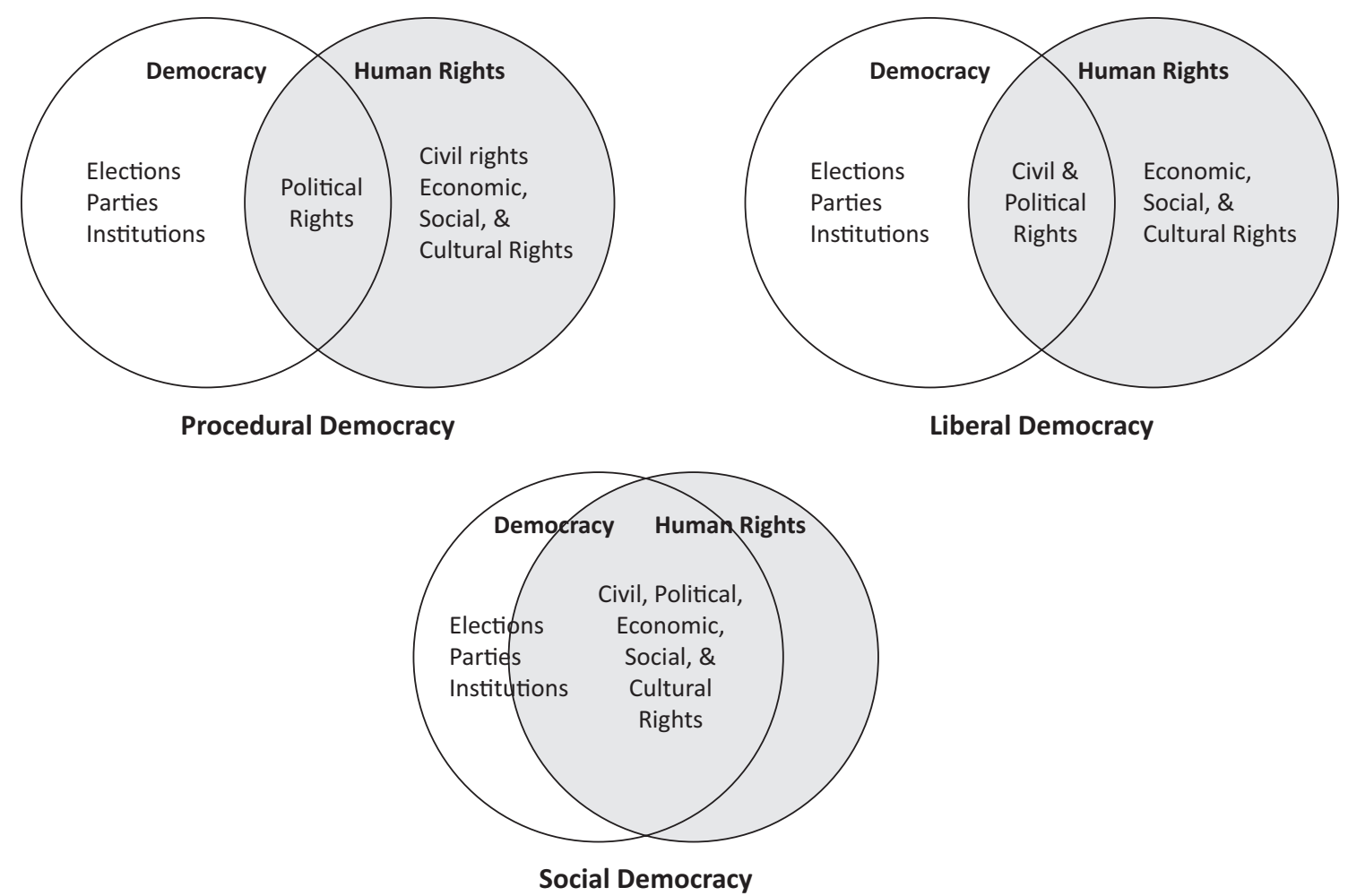

Figure 1. Definitions of democracy (adapted from Beetham, 1999, p. 94).

cally include freedom from torture, arbitrary detention, extra-judicial killing, and exile (see Poe \& Tate, 1994). It is not clear from the literature on democracy or human rights that human rights beyond this more limited set are indeed necessarily part of the concept of democracy. Where Hill (2016) is correct is with respect to the endogeneity problem in the empirical analysis of the relationship between democracy and human rights as we shall see in subsequent discussions below.

The possibility of different definitions and different degrees of overlap necessarily affects the ways in which both concepts are measured and analysed (Coppedge, 2012); however, there has not been much discussion about this particular issue in the measurement literature (see Munck, 2009), since there are discussions on the measurement of democracy or human rights, but not democracy and human rights. Moreover, discussions of the measurement of democracy, as well as the empirical operationalisation of democracy include measures that are arguably more about human rights than democracy per se. For example, in her review of existing measures of democracy, Dorenspleet (2015) includes scales produced by Freedom House, where the checklists for at least one of the scales focuses almost exclusively on human rights. Helliwell (1994) combines these two Freedom House measures arithmetically and calls the combination an 'index of democracy', a move which necessarily commits him to a specific concept of democracy and inclusion of some human rights but not all. These and other tensions in the measurement of democracy and human rights are discussed in turn.

\section{Measurement Strategies}

The measurement of democracy and human rights has progressed significantly since the early modernization literature as seen in the seminal studies from Seymour Martin Lipset (1959) on the world and Daniel Lerner (1958) on the Middle East. Simple dichotomous coding schemes, although still adopted in some cross-national research (Przeworski et al., 2000) have given way to more complex formats that that seek to capture different dimensions of democracy (Coppedge et al., 2016) and an expanding set of human rights categories beyond civil and political rights to include economic and social rights (Fukuda-Parr, Lawson-Remer, \& Randolph, 2015; Landman, 2002, 2006; Landman \& Carvalho, 2009; Landman \& Häuserman, 2003; Landman \& Kersten, 2016). This development in measures has also included an expansion in the different types of data used to measure the two concepts, including events data, standards data, survey data, socio-economic and administrative data, and increasingly, so-called 'big' data (Landman \& Kersten, 2016).

\subsection{Events}

Events-based data answer the important questions of what happened, when it happened, and who was involved, and then report descriptive and numerical summaries of the events. For human rights, counting such events and violations involves identifying the various acts of commission and omission that constitute or lead to human rights violations, such as extra-judicial killings, 
arbitrary arrest, or torture. Such data tend to be disaggregated to the level of the violation itself, which may have related data units such as the perpetrator, the victim, and the witness (Ball, Spirer, \& Spirer, 2000; Landman, 2006, pp. 82-83; Seybolt, Aronson, \& Fischoff, 2013). Events data are used less frequently in research on democracy, but Lindberg (2006) used the number of elections as an indicator of the growth of democracy in Africa alongside other attributes of democracy. Other democratic events can include transitions from authoritarian rule as in the large literature on 'waves' of democracy (see Doorenspleet, 2005; Huntington, 1991; Landman, 2013; Landman \& Carvalho, 2017). In his work on democratic performance, Lijphart $(1994,1999,2012)$ incorporates a number of events data to judge the relative merits of consensus and majoritarian democracies, but these events are not 'democratic' per se. Rather, they are measures of government performance more generally and are hypothesised as areas of performance that should be (1) superior among democracies and (2) differentiated between consensus and majoritarian forms of democracy.

\subsection{Standards}

Standards-based measures of democracy and human rights are one level removed from event counting and/or violation reporting and merely apply an ordinal scale to qualitative information, where the resulting scale is derived from determining whether the reported democratic or human rights situation reaches particular threshold conditions. Standards-based scales have been the workhorse of cross-national research in comparative politics, development studies, international political economy, and international relations. One of the major challenges with standards-based scales has been the multiplicity of their use, where such scales are used as measures of democracy, human rights, the 'repressiveness of the regime', the rule of law, and 'good governance' (Foweraker \& Landman, 1997; Landman, 2005a; Landman \& Hauserman, 2003; Muller \& Seligson, 1987). There has been a hasty and particular readiness to use such measures without careful reflection on the concepts that underpin them, the attributes that inform their coding, and the potential overlaps between democracy and human rights that arise (see also Munck, 2009).

There are prominent examples of standards-based measures of democracy. In the Cross-Polity Time-Series Data Archive, Arthur S. Banks provided standards-based scales of different institutional attributes of democracy (see Foweraker \& Landman, 1997). The scales were coded for the presence of these attributes and can be totalled for a democracy score that measures the narrow form of procedural democracy. The Polity IV data set provides standards-based measures of different democratic attributes, and focusses on the constraints on the regulation, openness and competitiveness of the executive branch, alongside constraints on the executive and the regulation and competitiveness of participation. Like Banks, these different attributes can be analysed separately (see Buena de Mesquita, Downs, Smith, \& Cherif, 2003) or used together to form a scale that ranges from autocracy to democracy (Marshall, Gurr, \& Jaggers, 2016). In similar fashion, the 'scale of polyarchy' (Coppedge \& Reinicke, 1988) indicators of freedom of expression, freedom of organization, media pluralism, and the holding of fair elections; where this approach has influenced the approach taken in the much expanded 'varieties of democracy' project.

For human rights, the most prominent standardsbased examples include the Freedom House scales of civil and political liberties (Gastil, 1980; www.freedom house.org), the 'political terror scale' (Poe \& Tate, 1994), a scale of torture (Hathaway, 2002), and a series of seventeen different rights measures collected by Cingranelli and Richards (www.humanrightsdata.com). Freedom House has a standard checklist it uses to code civil and political rights based on press reports and country sources about state practices and then derives two separate scales for each category of rights that range from 1 (full protection) to 7 (full violation). The political terror scale ranges from 1 (full protection) to 5 (full violation) for state practices that include torture, political imprisonment, unlawful killing, and disappearance. Information for these scales comes from the US State Department and Amnesty International country reports. In similar fashion, Hathaway (2002) measures torture on a 1 to 5 scale using information from the US State Department. The Cingranelli and Richards human rights data codes similar sets of rights on scales from 0 to 2 , and 0 to 3 , with some combined indices ranging from 0 to 8 , where higher scores denote better rights protections. In addition to a series of civil and political rights, Cingranelli and Richards also provide measures for such rights as women's economic, social, and political rights, worker rights, and religious rights.

One of the key issues that emerged concerning these human rights scales has been the level of awareness in general about human rights and whether an increased awareness and expectation of accountability for human rights violations would increase the reporting of observations of human rights and thus make the world appear worse off over time than was actually the case. Christopher Fariss (2014) addresses this issue head on through the use of item-response theory (IRT) and applies it to existing human rights scales. The intuition behind the item-response theory is that discerning the location of a country on the scale involves a judgment about the degree to which a country meets the threshold condition to move it from one category in the scale to the next. Fariss (2014) finds that when the scales are readjusted for this process of discernment and raised expectation about human rights accountability the overall picture of human rights remains positive over time. Even though the world is more conscious of human rights (itself a function of successful advocacy by human rights organisations), the 
underlying trends in human rights abuse over the last three decades have seen a gradual improvement.

\subsection{Surveys}

There are countless survey projects on democracy, in terms of electoral studies and public attitudes, support for democracy, support for democratic institutions, satisfaction with democracy and voter intention among other dimensions of democracy. Large survey projects like the World Values Survey and the 'Barometer' projects for Europe, Africa, Latin America and Asia have all used random samples and structured survey frameworks that have been used for primary and secondary analysis of citizen attitudes across wide range of concerns relevant to democracy. In addition to random sample approaches, there are 'expert judgement' surveys on democracy, such as the electoral integrity project (Norris, 2017), the Bertelsmann Transformation Index (www.btiproject.org) and the Varieties of Democracy project (see, e.g., Lührmann, Lindberg, \& Tannenberg, 2017).

Household surveys have been used to provide measures for popular attitudes about rights and to uncover direct and indirect experiences of human rights violations. Some of the most notable work has been carried out by the NGO Physicians for Human Rights, which conducts surveys of 'at risk' populations (e.g. internally displaced people or women in conflict) to determine the nature and degree of human rights violations (www.physiciansforhumanrights.org). The 'minorities at risk' project certainly captures the degree to which communal groups and other national minorities suffer different forms of discrimination (www.mar.umd.edu). In addition, truth commissions, such as East Timor (www.chegareport.net) and Sierra Leone (www.sierraleonetrc.org) have carried out retrospective household mortality surveys on all deaths and illnesses during the periods under investigation. These surveys are then used alongside events data in ways that allow for better estimations of the total number of people killed or disappeared during periods of conflict, occupation, or authoritarian rule. In similar fashion, Anderson, Paskeviciute, Sandovici and Tverdova (2005) use survey data alongside standards-based measures of human rights to compare the perceptions and attitudes on human rights in Eastern Europe to reported human rights conditions (see Landman \& Carvalho, 2009, pp. 91-106).

\subsection{Socio-Economic and Administrative Statistics}

Administrative and socio-economic statistics produced by national statistical offices or recognized international governmental organizations have been increasingly seen as useful sources of data for the indirect measure of human rights, or as indicators for rights-based approaches to different sectors, such as justice, health, education, and welfare. Government statistical agencies and intergovernmental organizations produce a variety of socio- economic statistics that can be used to approximate measures of human rights. For example, academic and policy research has used aggregate measures of development as proxy measures for the progressive realization of social and economic rights. Such aggregate measures include the Physical Quality of Life Index (PQLI), the Human Development Index (HDI) and the Social Economic Rights Fulfilment Index (SERF Index). the SERF Index (www.serfindex.org) measures on a 0 to 100 scale the extent to which states fulfil their obligations under the right to food (infant height and weight), the right to education (primary school completion, gross school enrolment, average math and science PISA score), the right to health (contraceptive prevalence, life expectancy, infant mortality), the right to housing (improved access to sanitation and water), and the right to work (poverty headcount, long-term unemployment, relative poverty) in relation to countries' maximum available resources.

The World Bank's governance indicators have collated a panoply of different indicators from which six main dimensions of governance are derived (Kaufmann, Kraay, \& Mastruzzi, 2009). Tatu Vanhanen has dedicated his life's research to the growth and development of democracy and his main measure the Index of Democratization is comprised of 'objective' measures of his key dimensions of democracy that draw on Dahl (1971): participation and competition. For participation, he uses the official electoral turnout of the population. For competition, he uses the size of the smallest political party in the legislative chamber. His index then multiplies these two dimensions, which he argues captures the essence of democracy (see, e.g. Vanhanen, 2003).

More interestingly, Foweraker \& Krznaric (2003) use different official statistics to differentiate democratic performance of established democracies in the West. They argue that extant measures of democracy like the Polity IV measure provide very little indication of the variation in established democracies, and lead to the conclusion that these democracies and their performance are both uniform and superior to other new and restored democracies (Foweraker \& Krznaric, 2003, p. 314). They show that these established democracies are not necessarily uniform, and that there are deficiencies in civil and minority rights protections, such as women's representation, equal access to the law, and political discrimination against minorities, as well as disproportionately high incarceration rates (Foweraker \& Krznaric, 2003, p. 327). These problem areas are particularly acute in the US, the UK and Australia (Foweraker \& Krznaric, 2003, pp. 327-332), while their overall conclusions shed considerable insight into the variation in well-established democracies particularly in the realm of human rights (see below).

\subsection{New Forms of Data}

In addition to the continued development and refinement of these existing measurement strategies, there 
are new trends in data collection that make use of the 'democratization of technology' that has taken place more or less during the first decade of the twenty-first century. The rise of social media and the increasing availability of smartphones and other mobile devices has led to a revolution in the ability of individual people to have a voice in ways that were hitherto not possible. User-generated content on the Internet, in the form of 'tweets', YouTube videos, SMS alert networks, and other platforms of information dissemination, have created a volume of information on country conditions that is beginning to transform the ability of political scientists and other researchers to study human rights. The information that is now available is 'double edged': on the one hand, it provides the ability for grassroots reporting and narrative accounts of real time events as they unfold, and on the other hand, it provides 'meta data' on the events themselves, as smart technology often contains automatic functions that include the date, time and location that something has happened (typically through embedded 'global positioning system' technology, or GPS).

The combination of real time data and meta data allows for collection, fusion, and visualization of democracy and human rights events across space and time, often at the 'street corner' level of accuracy. The collection of these kinds of data occurs in two ways: (1) 'crowd sourcing' through specialized data collection 'portals' such as the platform made available through Ushahidi (www.ushahidi.com), or (2) collection of data from already existing 'open data' sources, such as Facebook, Twitter, news media, and NGO reporting, among others. In their raw form, the data are not particularly useful, but, through fusing different sources into well-structured data bases that conform to the 'who did what to whom' understanding of human rights violations, they can be used for human rights assessments of countries. Moreover, since the meta data may contain additional information about date, time, and location of events, it is possible to map violations on publicly available mapping programmes, such as Google Maps.

\section{Empirical Relationships}

The theoretical connections and overlaps set out above show that it is not unreasonable to expect strong empir- ical relationships between democracy and human rights. Democracies are meant to be based on the protection of fundamental rights and thus there is an expectation that human rights protections will be higher in democracies than non-democracies or that the protection of human rights will co-vary with the level of democracy. Large scale cross-national comparative analyses that specify civil and political rights protection as the dependent variable tend to use a narrow and procedural definition of democracy as an independent variable (see, e.g. Landman, 2005a, 2005b; Landman \& Carvalho, 2016; Mitchell \& McCormick, 1988; Poe \& Tate, 1994) in an effort to minimise the problem of endogeneity. Such studies show that democracy and human rights are indeed positively correlated with one another but not perfectly so. From the first cross-national study by Mitchell \& McCormick (1988) to the latest pooled-cross section time-series models on human rights protection, there is a significant relationship between democracy and human rights.

For example, Table 1 shows the correlations between democracy and human rights using a variety of measures across a different selection of country cases and time (Landman, 2005a, p. 110, 2016, p. 144). The first row in the table includes correlations for the Polity IV measure of democracy and different measures of human rights for a sample of 194 countries between 1976 and 2000, which are all statistically significant and indicate varying magnitudes in the relationship between democracy and human rights. The negative signs for these correlations are due to the fact the democracy scores are coded low for non-democracy and high for full democracy, while human rights scores (with the exception of Cingranelli and Richards) are coded low for good human rights protection (or low levels of violation) and high for bad human rights protection (or high levels of violation). The second row is a set of correlations for a sample of 21 Latin American countries between 1981 and 2010 (Landman, 2016, p. 144) using the same Polity IV variable and a slightly different set of human rights measures, including the Amnesty International derived Political Terror Scale, US State Department derived Political Terror Scale, and the Cingranelli and Richards (CIRI) physical integrity rights scale. ${ }^{1}$ While all these correlations are significant at the $p<.001$ level of significance, the magnitude varies from relatively low values to high values suggesting that

Table 1. Correlations between democracy and human rights.

\begin{tabular}{lllllll}
\hline & PTS & PTS & Civil Liberties & $\begin{array}{l}\text { Political Rights } \\
\text { (F House) }\end{array}$ & $\begin{array}{l}\text { Torture } \\
\text { (Hathaway) }\end{array}$ & $\begin{array}{l}\text { Physical Integrity } \\
\text { (CIRI) }\end{array}$ \\
\hline World & $-.36^{* * *}$ & $-.41^{* * *}$ & $-.85^{* * *}$ & $-.91^{* * *}$ & $-.34^{* * *}$ & $(.000)$ \\
$1976-2000^{1}$ & $(.000)$ & $(.000)$ & $(.000)$ & $(.000)$ & $.35^{* * *}$ \\
\hline Latin America & $-.27^{* * *}$ & $-.38^{* * *}$ & & & $(.000)$ \\
$1981-2010^{2}$ & $(.000)$ & $(.000)$ & & & \\
\hline
\end{tabular}

Notes: Pairwise correlations, $\mathrm{p}$-values in parentheses, ${ }^{*} \mathrm{p}<.10 ;{ }^{* *} \mathrm{p}<.05 ;{ }^{* * *} \mathrm{p}<.001$; Landman $(2005 a, 2016, \mathrm{p} .144)$.

\footnotetext{
${ }^{1}$ The coding for this scale is the inverse of what is used across the other scales and thus is positively correlated with the Polity IV measure of democracy.
} 
democracy and human rights certainly co-vary, but not perfectly so.

This variation in the magnitude of the relationship between the particular measure of democracy and these different human rights measures suggests several things. First, these measures are indeed measuring different things. The Polity IV measure primarily captures the institutional dimension of democracy, while the human rights measures focus on a narrow set of physical integrity rights (the Political Terror Scale and the CIRI scale) and torture (Hathaway, 2002) or on broader sets of civil and political rights (Freedom House), where there is much more conceptual (and therefore empirical) overlap between democracy and human rights. Indeed, the coding checklists for the Freedom House measures include attributes most commonly associated with democracy. Second, the gap between democracy and human rights evident in correlations that are less than a perfect 1 capture the notion of what Larry Diamond (1999) and Fareed Zakaria (2003) have called 'illiberal democracies', where it is perfectly possible for democracies to hold elections, have peaceful transfers of power between civilian leaders, and functioning legislatures while at the same time being unable to prevent the violation of certain human rights (see Beetham et al., 2008; Landman, 2016). To demonstrate this point further, it is possible to combine standards-based measures of civil and political rights seen in Table 1 above into a single factor score and then plot this factor score against the Polity IV measure of democracy. There are strong and significant factor loadings ranging from .684 to .909 for each of five measures of human rights on a single extracted factor component that is common to all measure (see Landman \& Larizza, 2009, p. 721). Figure 2 shows a scatter plot between the Polity IV measure of democracy and this human rights factor (see Landman, 2013, p. 39; Landman, Kernohan, \& Gohdes, 2012; Landman \& Larizza, 2009), where it is clear that there is a positive and significant re-

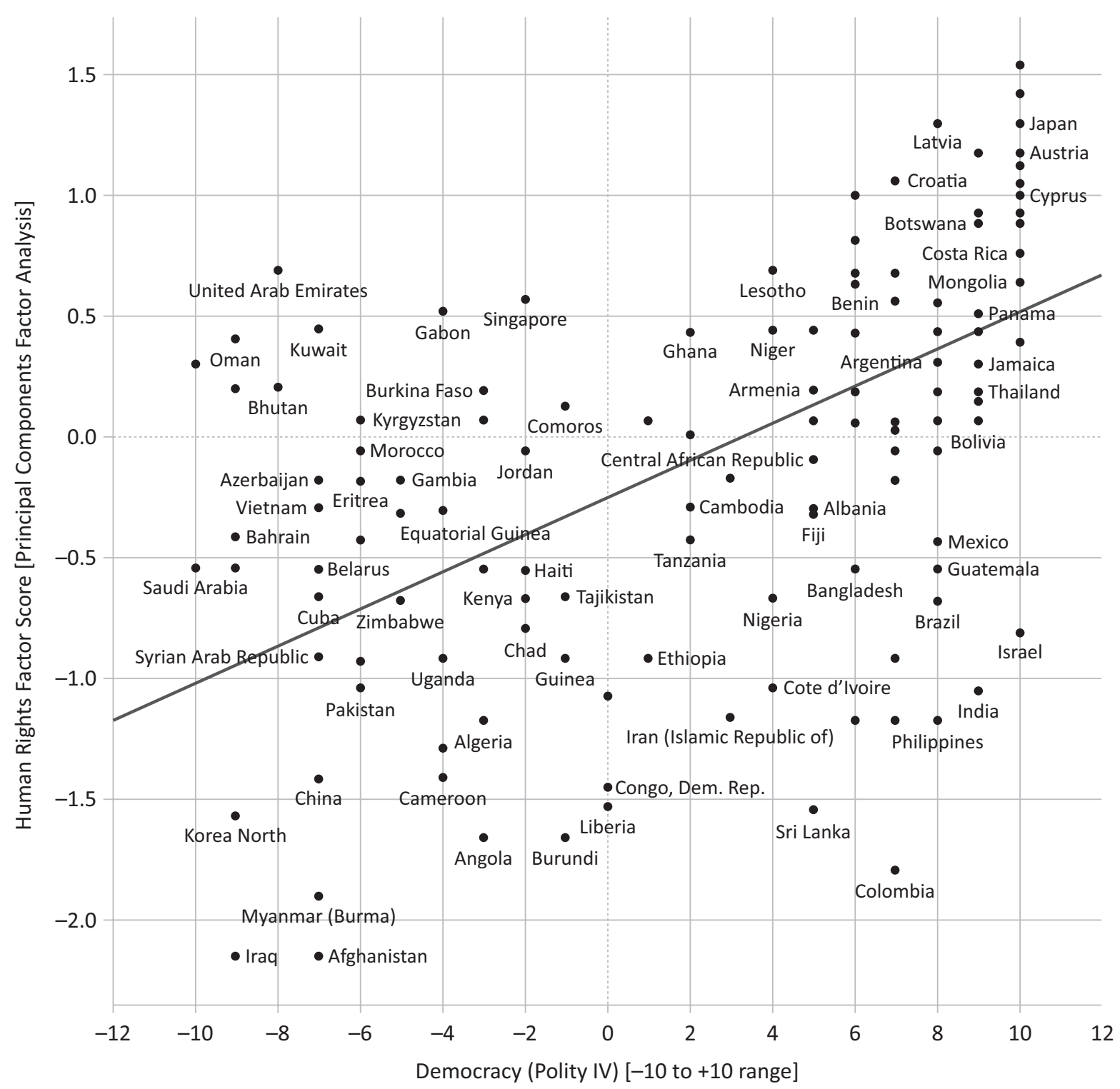

Figure 2. Democracy and Human Rights (2000). 
lationship between the two measures (captured by the fitted line). It is also evident from Figure 2 that there is a significant number of countries that would qualify as 'illiberal democracies' sitting in the lower right quadrant (e.g. Brazil, India, the Philippines, and Colombia). These countries score relatively high on democracy but relatively low on their ability to protect human rights. Third, the significant relationships can also be down to an element of human rights sitting within measures of democracy. Indeed, Hill (2016) has shown that democracy measures such as Polity IV have certain limited elements of human rights in them, rendering some empirical analysis between democracy and human rights spurious.

Beyond the relationship between democracy and civil and political rights, Fukuda-Parr et al. (2015, pp. 131-135) show that democracies have a much better record of fulfilling social and economic rights. Their Social and Economic Rights Fulfilment (SERF) Index ranges from 0 (no fulfilment) to 100 (expected fulfilment). They show that the 5th Quintile democracies (using the Polity IV measure of democracy) have a mean score on fulfilling social and economic rights of 80.92 with a low of 56.06 and a high of 94.05 , where this range is significantly better than for lower scoring democracies and autocracies (Fukuda-Parr et al., 2015, p. 132). These positive relationships for Polity IV and SERF are also upheld for the World Bank's Worldwide Governance Indicators on 'Voice and Accountability' and 'Rule of Law', and the Freedom House scales of political rights and civil liberties (Fukuda-Parr et al., 2015, pp. 132-133). For my own work on Latin America across 21 republics for the period 1980-2010, the SERF index is positively correlated with the Polity IV measure of democracy (Kendall's Tau $\mathrm{B}=.241, \mathrm{p}<.000)$ (Landman, 2016, pp. 144). Again, as in the relationships between democracy and civil and political rights, the fulfilment of social and economic rights is a function of more than just democracy, and that any relationship is not perfectly correlated. Rather, variation in democracy accounts for some of the variation in social and economic rights fulfilment.

The empirical relationship between democracy and human rights is highly variegated and dependent more on the definitions of democracy that are adopted than human rights, since human rights have been formally articulated through international and domestic law in ways that democracy has not. While there are no agreed philosophical foundations for the existence of human rights, the law of human rights across domestic, regional and international jurisdictions, as well as the jurisprudence that accompany it have provided what human rights lawyers call 'core content' of rights and their obligations. It is this core content and articulation of state obligations that in my view represent a 'systematized concepts' (Adcock \& Collier, 2001) that can be operationalized through the different types of data discussed here. In contrast, the concept of democracy relies only on political theory and political philosophy for its core content and has not been 'legalized' in the same way as human rights
(Meckled-Garcia, 2005). As we have seen, definitions of democracy vary considerably and variously include different sets of human rights. The positive and significant relationship between democracy and human rights attests to their complementarity, while the remaining gap in the relationship between them confirms that they are different from one another.

The utilization of measures for empirical analysis needs to be consistent in setting out what is (or is to be) measured, compared, and analysed; where any use of measures must be as closely linked to the concepts that they purport to measure. This linkage between concepts and measures involve significant trade-offs between complexity, viability, and validity (Landman \& Carvalho, 2009, pp. 24-30). It can be argued that there is a direct and negative relationship between conceptual complexity and measurement viability. Complex conceptual frameworks for measuring democracy and human rights might reduce viability, as complexity raises cost and faces challenges of data availability and accessibility. The four different types of data outlined here-events, standards, surveys, socio-economic and administrativecan and have been variously to capture part or most of each concept depending on the purpose of the empirical analysis (Landman \& Carvalho, 2009, p. 29).

\section{Challenges and Opportunities}

Democracy and human rights are complex, multi-faceted and multi-dimensional concepts that are not mutually exclusive from one another. Definitions of democracy variously include both institutional dimensions that constrain executives, separate power and authority, and provide mechanisms for accountability, as well as rights dimensions that provide fundamental protections that allow individuals and groups to aggregate their interests, articulate those interests, shield themselves from arbitrary abuses of power, and enjoy the ability to exercise freedom and agency in their public and private lives. The first and crucial step in any systematic effort to compare, measure, and analyse democracy and human rights is to provide precise and coherent definitions of the concepts to be measured and analysed, the boundary conditions for them, and the attributes that comprise them.

It for the reasons of complexity, multi-dimensionality, and variable overlap between democracy and human rights that measurement strategies have been difficult, challenging, and evolving. Different attributes of democracy and human rights can be delineated through different indicators, which can yield different 'scores on units' (Adcock \& Collier, 2001, p. 201) that vary across space and over time. Many of these attributes and dimensions are observable, while many are not, where lateral methods, proxy measures, and 'latent class' analytical techniques and probabilistic inferential statistics (such as multiple systems estimation, or MSE) are required. Overt elements of democracy and human rights such as elections and violations can be observed and 
counted, while many aspects suffer from what the late Will Moore calls 'the fundamental problem of unobservability', where practices, actions, choices, and interpersonal interactions take place behind closed doors and in secret locations.

The scholarly and practitioner communities working on democracy and human rights have made great strides in developing increasingly nuanced and effective measurement strategies that have captured more of the inherent complexity and multi-dimensionality of democracy and human rights. Events-based data, standardsbased data, survey-based data, and socio-economic and administrative statistics are being used in increasingly creative and systematic ways to capture the temporal and spatial variation in democracy and human rights. From Lipset's (1959) original polychotomous coding to the latest release of the Varieties of Democracy (V-Dem) data set, there have been great strides made in the measurement and analysis of democracy, the quality of democracy, and democratic performance. From the early work of Gastil to the latest analysis from Fariss (2014) and the Human Rights Data Analysis Group (HRDAG), there have been significant advances in the measurement and analysis of human rights (see www.hrdag.org).

Despite these many advances, however, many challenges remain. First, there is still the need to work on how democracy and human rights are defined and how those aspects that are unique to each are circumscribed, while greater attention is given to the different ways in which democracy and human rights overlap with one another and how they are related to one another. Second, the specification of systematic definitions of both concepts is directly linked to the ways in which they are measured. Third, there continues to be an over-reliance on subjective coding of subjective information collected on democracy and human rights. Now more than ever, there are increasing types of data being generated that can be harnessed and analysed in ways that can enhance our understanding and explanation of the variation in democracy and human rights. Big data techniques, machine learning and supervised machine learning, web scraping and corpus linguistic analytical techniques offer new ways of measuring, mapping, and understanding democracy and human rights.

\section{Conflict of Interests}

The author declares no conflict of interests.

\section{References}

Adcock, R., \& Collier, D. (2001). Measurement validity: A shared standard for qualitative and quantitative research. American Political Science Review, 95(3), 529-546.

Anderson, C. J., Paskeviciute, A., Sandovici, M. E., \& Tverdova, Y. V. (2005). In the eye of the beholder? The foundations of subjective human rights conditions in East-Central Europe. Comparative Political Studies, 38(7), 771-798.

Ball, P. B., Spirer, H. F., \& Spirer, L. (Eds.). (2000). Making the case: Investigating large scale human rights violations using information systems and data analysis. Washington, DC: American Association for the Advancement of Science (AAAS).

Banks, A. S. (1971). Cross-polity time series archive. Cambridge, MA: MIT Press.

Beetham, D. (1999). Democracy and human rights. Cambridge: Polity.

Beetham, D., Carvalho, E., Landman, T., \& Weir, S. (2008). Assessing the quality of democracy: A practical guide. Stockholm: International IDEA.

Brandal, N., Bratberg, $\varnothing$., \& Thorsen, D. (2013). The Nordic model of social democracy. London: Palgrave Macmillan.

Buena de Mesquita, B., Downs, G. W., Smith, A., \& Cherif, F. M. (2003). Thinking inside the box: A Closer look at democracy and human rights. International Studies Quarterly, 49(3), 439-457.

Collier, D., \& Levitsky, S. (1997). Democracy with adjectives: Conceptual innovation in comparative politics. World Politics, 49(3), 430-451.

Coppedge, M., Lindberg, S., \& Skaaning, S.-E. (2016). Measuring high level democratic principles using the V-Dem data. International Political Science Review, 37(5), 580-593.

Coppedge, M., \& Reinicke, W. (1988). A scale of polyarchy. In R. D. Gastil (Ed.), Freedom in the world: Political rights and civil liberties, 1987-1988 (pp. 101-121). New York, NY: Freedom House.

Coppedge, M. (2012). Democratization and research methods. Cambridge: Cambridge University Press.

Dahl, R. A. (1971). Polyarchy: Participation and opposition. New Haven, CT: Yale University Press.

Diamond, L. (1999). Developing democracy: Toward consolidation. Baltimore, MD: Johns Hopkins University Press.

Doorenspleet, R. (2005). The fourth wave of democratization: Identification and explanation (Doctoral dissertation). University of Leiden, Leiden, The Netherlands.

Fariss, C. J. (2014). Respect for human rights has improved over time: Modelling the changing standard of accountability. American Political Science Review, 108(2), 297-318.

Foweraker, J., \& Kznaric, R. (2000). Measuring liberal democratic performance: An empirical and conceptual critique. Political Studies, 48(2), 759-787.

Foweraker, J., \& Kznaric, R. (2003). Differentiating the democratic performance of the West. European Journal of Political Research, 42(3), 313-340.

Foweraker, J., \& Landman, T. (1997). Citizenship rights and social movements: A comparative and statistical analysis. Oxford: Oxford University Press.

Freeman, M. (2017). Human rights (3rd ed.). Cambridge: Polity. 
Fukuda-Parr, S., Lawson-Remer, T., \& Randolph, S. (2015). Fulfilling social and economic rights. Oxford: Oxford University Press.

Gallie, W. B. (1956). Essentially contested concepts. Proceedings of the Aristotelian Society, 56(1), 167-198.

Gastil, R. D. (1980). Freedom in the world: Political rights and civil liberties. Westport, CT: Greenwood Press.

Hathaway, O. (2002). Do treaties make a difference? Human rights treaties and the problem of compliance. Yale Law Journal, 111(4), 1932-2042.

Helliwell, J. (1994). Empirical linkages between democracy and economic growth. British Journal of Political Science, 24(2), 225-248.

Hill, D. (2016). Democracy and the concept of personal integrity rights. The Journal of Politics, 78(3), 822-835.

Huntington, S. (1991). The third wave: Democratization in the late twentieth century, Norman, OK: University of Oklahoma Press.

Kaufmann, D., Kraay, A., \& Mastruzzi, M. (2009). Governance matters VIII: Aggregate and individual governance indicators (Policy Research Working Paper). Washington, DC: World Bank.

Koch, I. E. (2005). Dichotomies, trichotomies, or waves of duties? Human Rights Law Review, 5(1), 81-103.

Landman, T. (2002). Comparative politics and human rights. Human Rights Quarterly, 43(4), 890-923.

Landman, T. (2005a). Review article: The political science of human rights. British Journal of Political Science, 35(3), 549-572.

Landman, T. (2005b). Protecting human rights: A global comparative study. Washington, DC: Georgetown University Press.

Landman, T. (2006). Studying human rights. Oxford and New York, NY: Routledge.

Landman, T. (2009). Human rights (volumes I-IV). London: Sage.

Landman, T. (2013). Human rights and democracy: The precarious triumph of ideals. London: Bloomsbury Academic.

Landman, T. (2016). Democracy and human rights: Explaining variation in the record. In J. Foweraker \& D. Trevizo (Eds.), Democracy and its discontents in Latin America (pp. 121-132). Boulder, CO: Lynne Rienner.

Landman, T., \& Carvalho, E. (2009). Measuring human rights. London and Oxford: Routledge.

Landman, T., \& Carvalho, E. (2017). Issues and methods in comparative politics. London and Oxford: Routledge.

Landman, T., \& Häusermann, J. (2003). Map-making and analysis of the main international initiatives in developing indicators of democracy and good governance. Luxembourg: Eurostat.

Landman, T., Kernohan, D., \& Gohdes, A. (2012). Relativising human rights. Journal of Human Rights, 1(4), 460-485.

Landman, T., \& Kersten, L. (2016). Measuring human rights. In M. Goodhart (Ed.), Human rights: Politics and practice (3rd ed., pp. 127-144). New York, NY: Oxford University Press.
Landman, T., \& Larizza, M. (2009). Inequality and human rights: Who controls what when and how. International Studies Quarterly, 53(3), 715-736.

Lerner, D. (1958). The passing of traditional society: Modernizing the Middle East. Glencoe, IL: The Free Press of Glencoe.

Lijphart, A. (1994). Democracies: Forms, performance, and constitutional engineering. European Journal of Political Research, 25(1), 1-17.

Lijphart, A. (1999). Patterns of democracy: Government forms and performance in thirty-six countries. New Haven, CT: Yale University Press.

Lijphart, A. (2012). Patterns of democracy: Government forms and performance in thirty-six countries (2nd ed.). New Haven, CT: Yale University Press.

Lindberg, S. (2006). Democracy and elections in Africa. Baltimore, MD: Johns Hopkins University Press.

Lipset, S. M. (1959). Some social requisites for democracy: Economic development and political legitimacy. The American Political Science Review, 53(1), 69-105.

Lührmann, A., Lindberg, S., \& Tannenberg, M. (2017). Regimes in the world (RIW): A robust regime type measure based on V-Dem (Working Paper. Series 2017: 47). Gothenburg: Varieties of Democracy Institute.

Macpherson, C. B. (1973). Democratic theory: Essays in retrieval. Oxford: Clarendon Press.

Marshall, M., Gurr, T. R., \& Jaggers, K. (2016). Polity IV project: Political characteristics and transitions, 1800-2015. Retrieved from http://www.systemic peace.org/inscrdata.html

Meckled-Garcia, S. (2005). The legalisation of human rights: Multidisciplinary approaches. Oxford: Routledge.

Mitchell, N. J., \& McCormick, J. M. (1988). Economic and political explanations of human rights violations. World Politics, 40(3), 476-498.

Muller, E. N., \& Seligson, M. A. (1987). Inequality and insurgency. American Political Science Review, 81(2), 425-451.

Munck, G. L. (2009). Measuring democracy: A bridge between scholarship and politics. Baltimore, MD: Johns Hopkins University Press.

Norris, P. (2017). Strengthening electoral integrity. New York, NY: Cambridge University Press.

Payne, L. (2000). Uncivil movements: The armed right wing and democracy in Latin America. Baltimore, MD: Johns Hopkins University Press.

Poe, S. C., \& Tate, C. N. (1994). Repression of human rights to personal integrity in the 1980s: A global analysis. American Political Science Review, 88(4), 853-872.

Przeworski, A. (1985). Capitalism and social democracy. Cambridge: Cambridge University Press.

Przeworski, A., Alvarez, M. E., Cheibub, J. A., \& Limongi, F. (2000). Democracy and development: Political institutions and well-being in the world, 1950-1990. Cambridge: Cambridge University Press. 
Seybolt, T. B., Aronson, J. D., \& Fischoff, B. (Eds.). (2013). Counting civilian casualties: An introduction to recording and estimating nonmilitary deaths in conflict. Oxford: Oxford University Press.

Sørensen, G. (1993). Democracy and democratization. Cambridge: Cambridge University Press.

United Nations. (1993). UN General Assembly, Vienna
Declaration and Programme of Action. Retrieved from http://www.refworld.org/docid/3ae6b39ec.html Vanhanen, T. (2003). Democratization: A comparative analysis of 170 countries. London: Routledge.

Zakaria, F. (2003). The future of freedom: Illiberal democracy at home and abroad. New York, NY: W.W. Norton.

\section{About the Author}

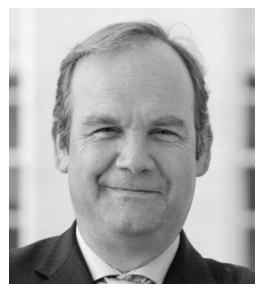

Todd Landman is Professor of Political Science and Pro Vice Chancellor of the Faculty of Social Sciences at the University of Nottingham. He is author of Issues and Methods in Comparative Politics (4th ed., Routledge 2017, with Edzia Carvalho), Democracy and Human Rights: The Precarious Triumph of Ideals (Bloomsbury 2013), Measuring Human Rights (Routledge 2009, with Edzia Carvalho), Studying Human Rights (Routledge 2006), Protecting Human Rights: A Comparative Study (Georgetown 2005), and Citizenship Rights and Social Movements: A Comparative and Statistical Analysis (Oxford 1997, with Joe Foweraker). He has carried out a large number of international consultancies on development, democracy and human rights. 